\title{
Nourishment of Perched Sand Dunes and the Issue of Erosion Control in the Great Lakes
}

\section{WILLIAM M. MARSH}

Department of Resource Science

The University of Michigan-Flint

Flint, Michigan 48502, USA

ABSTRACT / Although limited in coverage, perched sand dunes situated on high coastal bluffs are considered the most prized of Great Lakes dunes. Grand Sable Dunes on Lake Superior and Sleeping Bear Dunes on Lake Michigan are featured attractions of national lakeshores under National Park Service management. The source of sand for perched dunes is the high bluff along their lakeward edge. As onshore wind crosses the bluff, flow is accelerated upslope, resulting in greatly elevated levels of wind stress over the slope brow. On barren, sandy bluffs, wind erosion is concentrated in the brow zone, and for the Grand Sable Bluff, it averaged $1 \mathrm{~m}^{3} / \mathrm{yr}$ per linear meter along the highest sections for the period
1973-1983. This mechanism accounts for about $6,500 \mathrm{~m}^{3}$ of sand nourishment to the dunefield annually and clearly has been the predominant mechanism for the long-term development of the dunefield. However, wind erosion and dune nourishment are possible only where the bluff is denuded of plant cover by mass movements and related processes induced by wave erosion. In the Great Lakes, wave erosion and bluff retreat vary with lake levels; the nourishment of perched dunes is favored by high levels. Lake levels have been relatively high for the past 50 years, and shore erosion has become a major environmental issue leading property owners and politicians to support lake-level regulation. Trimming high water levels could reduce geomorphic activity on high bluffs and affect dune nourishment rates. Locally, nourishment also may be influenced by sediment accumulation associated with harbor protection facilities and by planting programs aimed at stabilizing dunes.

\section{Introduction}

The Great Lakes shorelines are bounded by more than $600 \mathrm{~km}$ of sand dunes. Among them is a variety of sand dunes called perched dunes. These are sand dunes situated along the top of coastal bluffs or cliffs of sandy composition. To many observers these are the most magnificent of Great Lakes' sand dunes. The two largest fields of perched dunes, Sleeping Bear on Lake Michigan and Grand Sable on Lake Superior, are featured attractions of the two largest national lakeshores in the Great Lakes. Our objective here is to report on sand nourishment to perched sand dunes based on more than 10 years of study of the Grand Sable Dunes and comment on the implications these findings have for lake and shoreline management policies and practices in the Great Lakes.

Perched sand dunes are found along most major coastlines of the world. They may occur in discrete fields, as at Sleeping Bear and Grand Sable, or interspersed with low-elevation dunes, i.e., those fed with sand from beach-level sources. Although several investigators (e.g., Bergquist 1936; Jennings 1967) attribute their origin to stranded deposits of beach sand from former elevated sea or lake levels, our research reveals that perched sand dunes originate from wind erosion of sand from exposures in the bank, bluff, or cliff on their seaward or lakeward edge (Marsh and Marsh 1987). The bluff may be composed of in situ materials (such as glacial deposits or sandstone), old dune deposits, or some combination of the two (Fig. 1). In all cases, however, wave erosion, shoreline retreat, and formation of a steep, devegetated bank are necessary in order to establish (1) the aerodynamic conditions for accelerated sand erosion, and (2) sand exposures to feed the wind.

\section{Airflow over Coastal Slopes}

Wind energy studies show that when onshore winds encounter long, wedge-shaped slopes, such as a bluff or escarpment, an aerodynamic form approximating a large standing wave develops windward of the slope. According to a model formulated by Bowen and Lindley (1977), in the area under the wave nearest the footslope, wind velocity is depressed to as much as 0.40 of that at a comparable elevation in the normal (flat-surface) wind velocity profile. Upslope velocity increases with height, and for slopes approaching $45^{\circ}$ reaches its greatest amplification, about 1.7 normal, across the brow of the slope (Fig. 2). ${ }^{1}$ Over a flat surface, such as a water body, wind velocity in the atmo-

\footnotetext{
'The airflow described here applies only to a simple slope form that is consistent over several kilometers of shoreline. It does not cover irregular, three-dimensional landforms such as a mountain ridge or most barrier dunes where the flow is much more complex.
} 


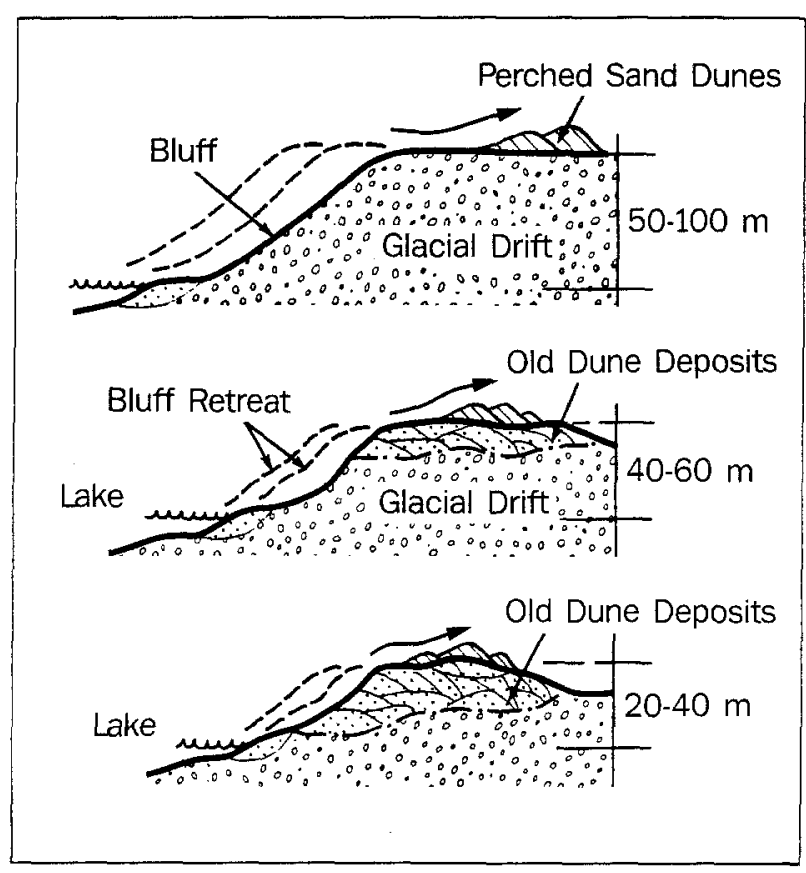

Figure 1. Perched sand dunes settings related to bluff height and composition. The largest fields in the Great Lakes are found on high bluffs composed of glacial drift.

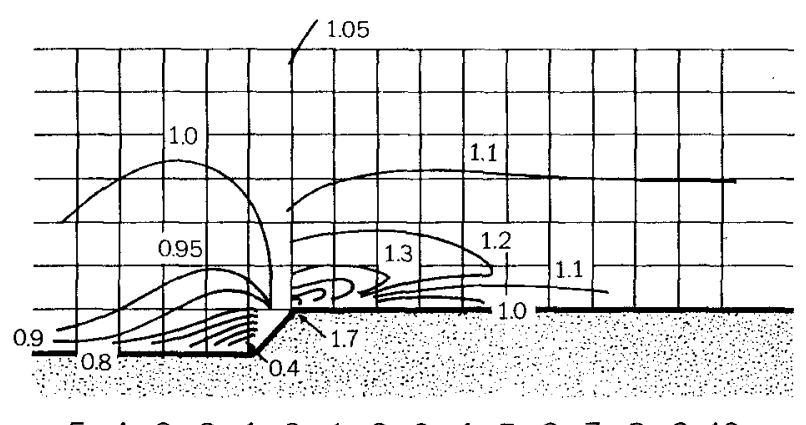

$\begin{array}{llllllllllllllll}5 & 4 & 3 & 2 & 1 & 0 & 1 & 2 & 3 & 4 & 5 & 6 & 7 & 8 & 9 & 10\end{array}$

Figure 2. Wind velocity amplification over a long wedgeshaped slope such as the Grand Sable Bluff. Values represent acceleration relative to the same elevation on the normal wind velocity profile in the boundary layer (Bowen and Lindley 1977).

spheric boundary layer (lower $300 \mathrm{~m}$ ) increases with height according to the normal velocity profile. Over a slope such as the Grand Sable Bluff, which approaches a height of $100 \mathrm{~m}$, the velocity of the onshore wind is some combination of slope amplification and the normal boundary layer profile.

The potential for wind erosion on level surfaces increases sharply with velocity (Bagnold 1953; White 1979):

$$
q=\frac{2.61 \rho}{g} V_{T}^{3}\left(\frac{V}{V_{T}}-1\right)\left(\frac{V^{2}}{V_{T}}+1\right)
$$

where $q$ is mass flux of sand, $\rho$ is air density, $g$ is gravity, $V_{T}$ is threshold velocity, and $V$ is drag or friction velocity. Because of the extraordinary increase in wind velocity with height on coastal bluffs and the exponential relationship between velocity and erosive force, the erosion potential reaches dramatic levels near the top. Although it is probably less than the theoretical estimates indicate (Bowen 1981, personal communication), the footslope to crestslope increase in the erosive potential of wind on high bluffs is probably in the 100- to 200-fold range (Marsh and Marsh 1987).

\section{Grand Sable Dunes and Bluff}

Grand Sable Dunes, where most of this research was conducted, are located on the south shore of Lake Superior between Marquette and Sault Ste. Marie, Michigan, U.S.A. The dunefield, which lies within the Pictured Rocks National Lakeshore, covers an area of about $9 \mathrm{~km}^{2}$ and is perched on a glacial deposit dating from the last contact of Pleistocene ice with the south rim of the eastern basin of Lake Superior, approximately 9,900 BP (Hughes and Merry 1978). The deposit is mainly composed of stratified sands and gravels that form three terracelike surfaces, the largest of which lies $80-90 \mathrm{~m}$ above Lake Superior. The northern edge of this feature is the Grand Sable Bluff, a wave-cut backshore slope stretching $7.65 \mathrm{~km}$ along the shore (Fig. 3). The bluff is inclined at angles between $35^{\circ}$ and $40^{\circ}$ and is oriented over most of its length roughly north-northwest, between $13^{\circ}$ and $23^{\circ}$ west of north. Exposure to northerly winds, which occur with high magnitudes and frequencies along southern Lake Superior, is therefore great. The bluff is almost entirely devegetated; however, patches of woody vegetation are found at several points along the crestslope and on several small sections of the bluff face. The beach at the toe of the bluff is narrow, $5-10$ $m$ wide, and highly active owing to wave erosion and groundwater seepage. These processes induce frequent mass movements in the bluff, which account for the barren character of the bluff face (Marsh and others 1973). This is extremely important in the nourishment of the dunefield as the barren bluff is highly susceptible to erosion by onshore winds.

\section{Wind Erosion and Dune Nourishment}

Bluff erosion by wind was determined from measurements of sand deposits along the top of the bluff in the zone immediately landward of the crestslope. Sites were selected where sand was blown directly from the bluff face across the brow and into a forest 


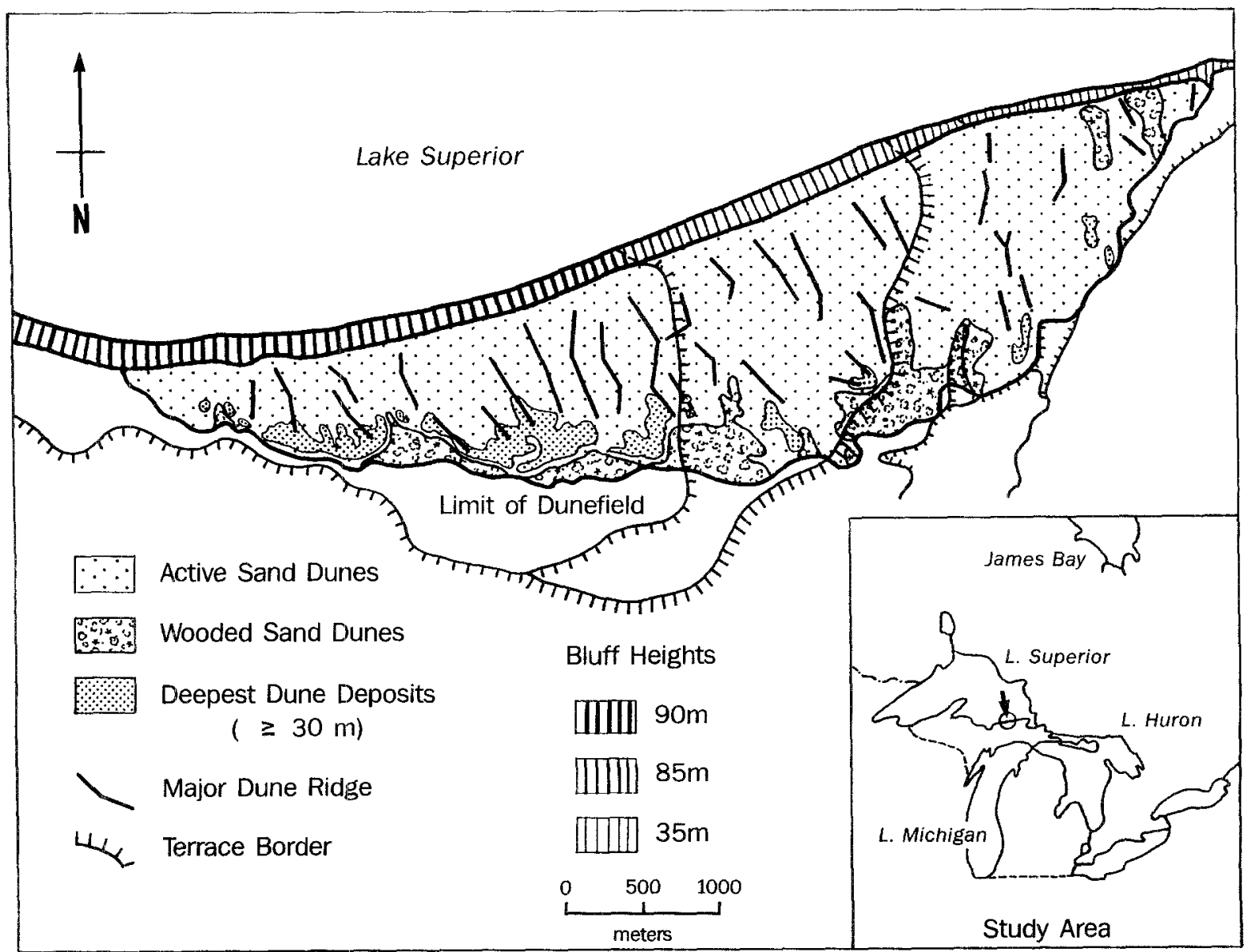

Figure 3. Grand Sable Dunefield and related features. The entire field is bordered by a high, sandy bluff on the lakeward edge. The landward border is the forest margin where the dunefield has advanced over trees. Forest also has vegetated some areas covered by dune sand.

canopy. The forest canopy acts as a sand trap in which the airborne sand precipitates onto the forest floor as wind undergoes flow separation leeward of the brow (Fig. 4a). Once the sand is deposited on the forest floor, it is protected from removal by opposing winds because of the large roughness length created by the tree cover.

Most sand drops out of the airstream within $20 \mathrm{~m}$ of the brow. After a number of years, a bermlike feature forms which Cooper (1958) called a precipitation ridge. The presence of this ridge, coupled with the high infiltration capacity of the sand, prohibits local runoff capable of transporting sand back to the bluff face. Thus the sand that accumulates on the forest floor at these sites is a reliable indicator of bluff erosion by onshore wind. Measurement of annual deposition on the precipitation ridges was based on three techniques: (1) comparing tree burial above the rooting level with tree age; (2) sampling the sand con- tent of snowbanks deposited over the ridge; and (3) measuring the thickness of sand layers interbedded with the annual layers of leaf litter in the ridge. The latter technique was reliable for deposits up to ten years old; in older deposits the litter was usually too decomposed to allow accurate discrimination. Most data were generated by the interbedding technique, and a summary of mean annual sand accumulation for the period 1973-1983 is presented in Figure 4b.

The total amount of sand eroded from the bluff by wind increases linearly with slope height. The mean annual yield of wind-blown sand from the largest slopes $(80-90 \mathrm{~m})$ is very close to $1 \mathrm{~m}^{3}$ per linear meter of slope (strike direction). For lower slopes, in the 35to $45-\mathrm{m}$ range, this values falls to around $0.4-0.5$ $\mathrm{m}^{3} / \mathrm{m}$. For bluffs cut into old dune deposits, the rate is probably greater because all the exposed material is at or below the threshold grain size for transport by modest winds, which is not the case on the bluffs cut 


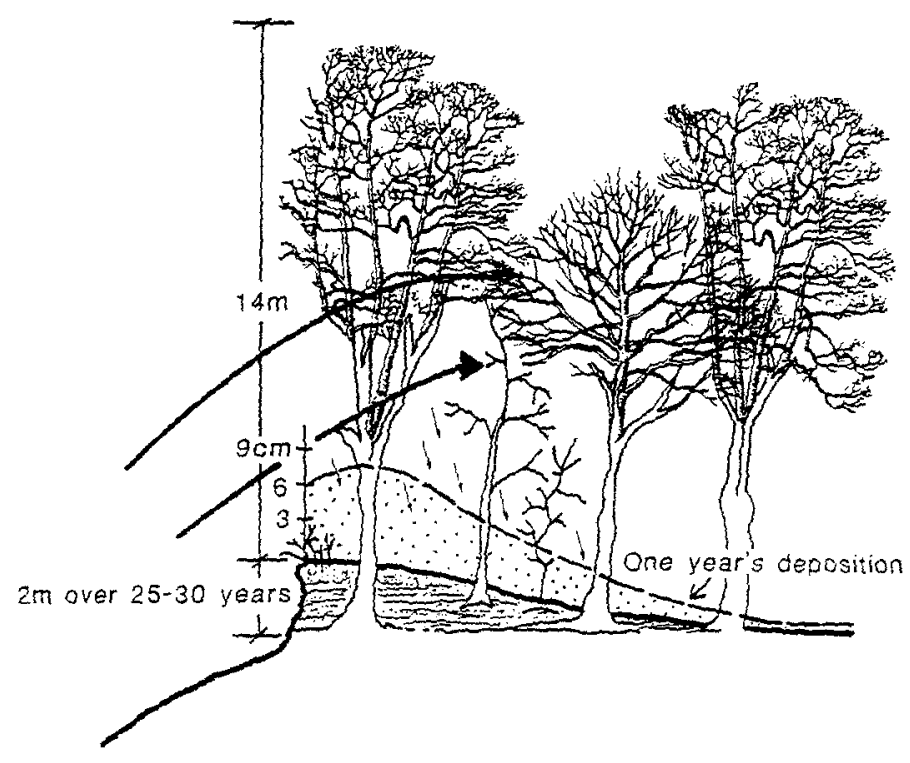

(a)

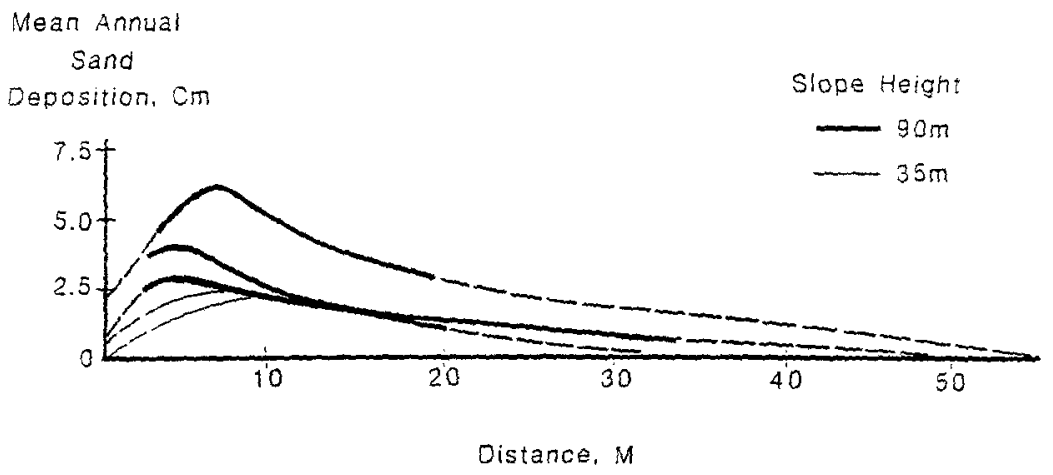

(b)

into coarser glacial deposits. Most wind erosion on Grand Sable Bluff, 50-70 percent of the annual total in most years, occurs in the cold season (November through March). The total nourishment to the dune field between 1973 and 1983 averaged close to 6,500 $\mathrm{m}^{3} / \mathrm{yr}$, enough sand each year to form a dune roughly $5 \mathrm{~m}$ high, $32 \mathrm{~m}$ wide, and $80 \mathrm{~m}$ long. Using this figure (with allowances for long-term variations in lake levels and bluff erosion) and the age of the dunefield $(9,900$ years), it is possible to account for the vast majority of sand currently in the dunefield by nourishment from onshore winds driving sand off the upper bluff (Marsh and Marsh 1987). Once in the dunefield, the sand is effectively trapped since there is no mechanism capable of removing more than small amounts of sand from the system. Southerly winds do transport sand lakeward in summer, but the quantity appears to be
Figure 4. a. Setting for the measurement of sand blown from the bluff. b. Sand nourishment from the bluff for five sites, $1973-1983$ significantly less than the annual landward flux judging from the lower magnitudes and frequencies of southerly winds and the lower incidence of deflation hollows on the southern flanks of sand dunes. Moreover, lakeward-moving sand that reaches the bluff is deposited just over the leeward (north) edge of the brow only to be blown back into the dunefield with the next northerly winds. Under very strong southerly flows, however, some of this sand reaches $50-75 \mathrm{~m}$ down the bluff face, where it may be lost to mass movement and runoff. During such events, fine particles, which constitute a very small part of the dune mass, also have been observed in suspension far beyond the bluff over Lake Superior.

Consistent with the airflow model in Figure 2, wind erosion is most concentrated in the upper part of the slope. Deflation begins near midslope and increases 
with distance upslope, reaching its greatest intensity across the crestslope. Where the crest is not defended by vegetation or resistant soil horizons, the brows of the highest slopes are reduced by wind erosion to a long convex form. Landward from the brow, the slope gives way to a flat deflation zone extending $50-100 \mathrm{~m}$ inland where the surface is dominated by pebble lag (Fig. 5). Beyond this barren zone lie the first significant dune deposits, irregular sand ridges aligned roughly north-northwest by south-southeast. The ridges increase in size downwind, culminating in a complex mass of dune deposits resembling a barrier dune formation $0.5-1.0 \mathrm{~km}$ inland.

This set of features and their spatial sequence conform very well to the wind-velocity patterns of the Bowen and Lindley (1977) model for airflow over a bluff or escarpment. The fastest air is concentrated across the crestslope, corresponding to the rounded brow. Beyond this point, fast air clings to the ground, corresponding to the deflation zone, and then separates from the surface at some distance downwind. Dune deposits begin at the point of flow separation. The distance from the crest at which separation occurs appears to be a general function of slope steepness, being smaller for steeper slopes according to Bowen and Lindley (1977).

Flow separation distance is also controlled by the morphology of the brow itself. Where the brow is angular because of reinforcing heavy root masses or soil horizons, as illustrated in Figure 4a, wind is diverted over the crestslope in a high trajectory. This causes almost immediate flow separation at the brow and a low velocity zone only $5-10 \mathrm{~m}$ downwind where airborne sand is deposited (Fig. 5c). Along the high sandstone cliffs of the nearby Pictured Rocks, where the brow form is sharply angular, small dunes form within $20 \mathrm{~m}$ of the crest. However, where the brow is rounded, as it is along the large perched dune fields, flow separation and dune deposits begin much farther inland, as much as $100-200 \mathrm{~m}$ from the bluff top in the most rounded parts of the bluff (Fig. 5a).

\section{Controls on Wind Erosion}

There are three primary controls on wind erosion: ground frost, gravel lag, and vegetation. Ground frost penetrates the slope to a depth of $2-3 \mathrm{~m}$ and, for the period of December through March, strengthens the sand substantially against wind erosion and mass movement (Dozier and others 1976). However, moisture contents are typically low in near surface sand $(<5 \%)$, and the ice crystals that bind particles together are readily sublimated when exposed to strong, dry winter winds. As a result, winter turns out to be the season of greatest wind erosion. As the bluff face is lowered by wind erosion, a veneer of coarse materials (pebbles and larger particles) builds up, which raises the roughness length and reduces sand erosion. Locally such lag surfaces are important in reducing wind erosion, but on the steeper parts of the bluff they are shortlived inasmuch as mass movements wipe them out soon after they form.

Vegetation is unquestionably the most effective control on wind erosion. Even light covers of rooted vegetation, such as moss and low, sparse grass, can reduce erosion to negligible levels on even the most stressed parts of the bluff (Marsh and Marsh 1987). It is also apparent that wind alone is ineffective in dislodging vegetation and exposing the underlying sand. Therefore, wind erosion is always consequent upon other processes, usually mass movements that cause wholesale removal of vegetation over large sections of slope face. Most mass movement on Great Lakes bluffs is brought on by wave erosion of footslopes.

\section{Management Implications}

The principal management implication of this study is the role of wave erosion and bluff retreat in the maintenance of perched dune fields. Wave erosion and bluff retreat are necessary to the nourishment of perched sand dunes. In general high lake levels are associated with the high rates of beach erosion and shoreline retreat (Quinn 1986; Larson 1973). This in turn promotes bluff failure, which inhibits the development of vegetative covers on the bluff faces. Therefore, during high water periods sand exposure on bluffs is at its maximum, and, all other things being equal, wind erosion and dune nourishment should also be at their greatest (Marsh and Marsh 1987). This contrasts with low-elevation dunes along Lake Michigan, where nourishment increases with lower lake levels and broader beaches (Olson 1958).

The historic record of Great Lakes levels reveals a range of fluctuation of about $2 \mathrm{~m}$ between record highs and lows (Quinn 1985, 1986). Although there is no true cycle to the pattern of recorded highs and lows, episodes of very high water $(0.5-1.0 \mathrm{~m}$ above mean datum) and accelerated shore erosion seem to occur every $10-15$ years or so. For large bluffs, there appears to be a time lag of five to ten years or so between high water and increased dune nourishment because most of the sand comes from the upper slope, the last part of the bluff activated by mass movements initiated by wave erosion. Likewise, large slopes take longer to stabilize when water levels fall; therefore, al- 


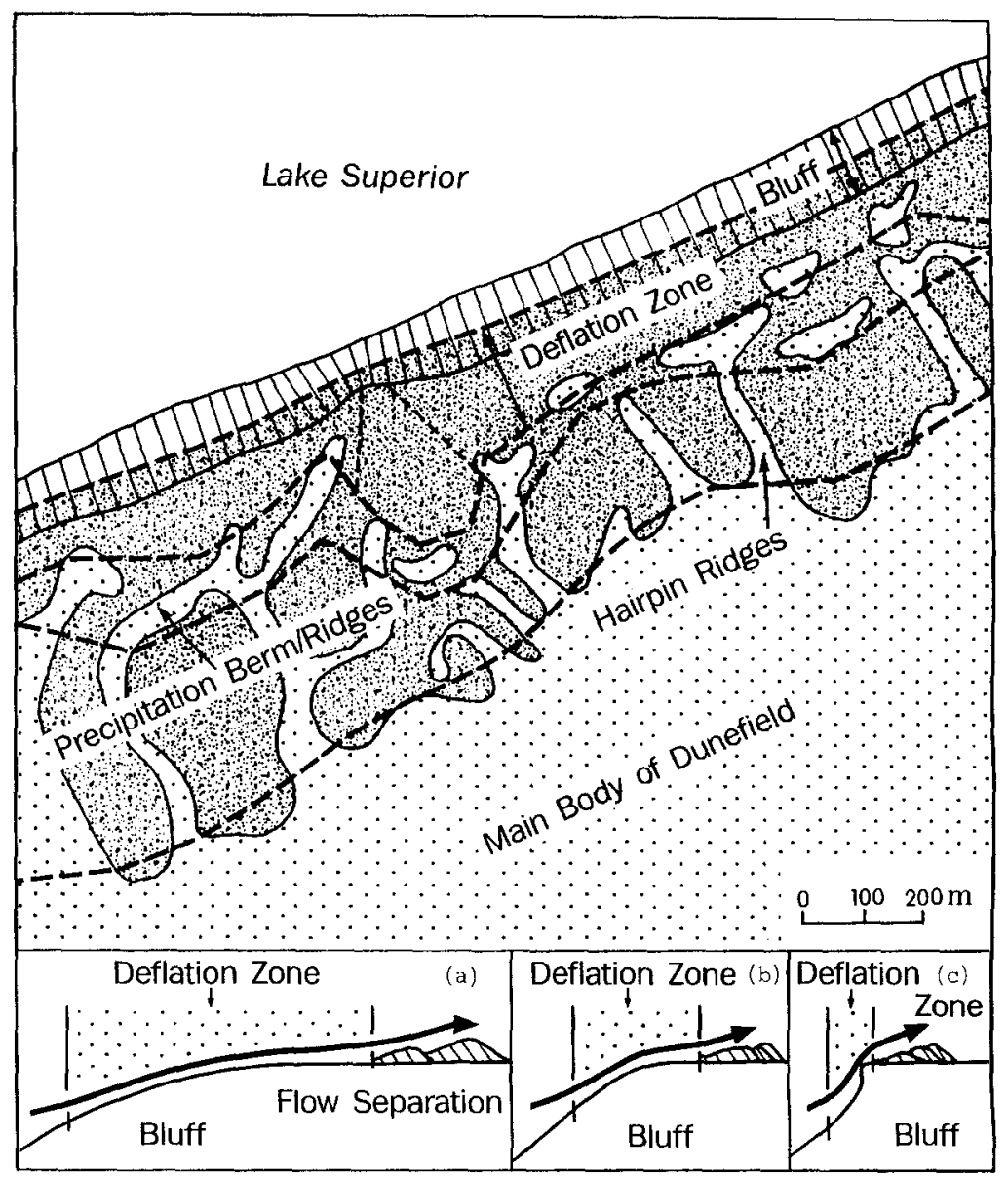

Figure 5. Top: the typical association of the bluff with the deflation zone and the zone of sand deposition. Bottom $(\mathbf{a}-\mathbf{c})$ : the influence of brow shape on the distance of flow separation and dune formation. though they are out of phase with lake level fluctuations, the net result is probably the same. Considered in a much longer time frame, the effect of lowered lake levels is apparent along postglacial Lake Nipissing bluffs, $10-12 \mathrm{~m}$ above current lake levels, which were abandoned 3,700-4,000 years ago (Lewis 1969). These bluffs today are fully forested and the perched dune fields along them, such as the one near Brimley, Michigan, which is less than $1 \mathrm{~km}$ inland of present south shore of Lake Superior, are inactive and forest covered.

Shore erosion is a serious problem in the Great Lakes. Of the $5,887 \mathrm{~km}$ of total shoreline, the U.S. Army Corps of Engineers (1971) classes $1,672 \mathrm{~km}$ $(28.4 \%)$ as eroding and $343 \mathrm{~km}(5.8 \%)$ as critical. Many factors contribute to shore erosion, but high water levels and erodible shore materials (mainly unconsolidated glacial deposits) are especially significant. Throughout the Great Lakes, efforts to reduce erosion have focused mainly on structural defense of vulnerable shorelines. In 1971, the Corps of Engineers listed $608 \mathrm{~km}(10.3 \%)$ of Great Lakes shoreline as having some sort of structural defense. With each episode of high water levels and increased shore erosion, the push to further shoreline defense efforts is renewed.

The largest wave-eroded slopes on the U.S. side of the Great Lakes are bluffs such as those of Grand Sable and Sleeping Bear dunes. Local citizens occasionally voice concern that retreat of these and similar bluffs represent a loss of valuable public property which could be corrected with wave defense and slope stabilization measures. The findings of this study indicate that where the perched dune itself is the management priority (as is the case in the national lakeshores) such a move would be ill advised as it would, if successful, eventually promote revegetating of the bluffs and reduce the nourishment to the dunes. Although wave defense structures appear to be ineffective in long-term erosion control, it is possible that bluffs currently close to the threshold of vegetation reestablishment could be brought to that state sooner, resulting in reduced levels of dune nourishment.

The administration of the Pictured Rocks National Lake Shore views structural defense of the Grand Sable Bluff as inadvisable from the Park Service's standpoint (Petersen 1987, personal communication). 
However, harbor protection structures, including a large breakwater, have been constructed at Grand Marais harbor 3,500 $\mathrm{m}$ downshore (east) of the Grand Sable Bluff. Behind (west of) this facility a large wedge of sand has accumulated since 1883, resulting in a widened beach extending 2,500-3,000 $\mathrm{m}$ toward the Grand Sable Bluff. Since 1961 the wedge has been growing at a rate of $38,000 \mathrm{~m}^{3} / \mathrm{yr}$ and Corps of Engineers projections show that by 2028 the wedge of sand could be less than $500 \mathrm{~m}$ from the eastern end of the Grand Sable Bluff (U.S. Army Corps of Engineers 1980). Should the wedge reach the eastern part of the bluff, it is sure to reduce bluff erosion there, which in turn will lower rates of dune nourishment (Fig. 6).

Another approach to the shore erosion problem is regulation of high water levels. At Sault Ste. Marie, discharge from Lake Superior is regulated in order to maintain shipping-channel depths and power-generating capacities. According to the International Joint Commission (IJC) (1976) (the American and Canadian committee responsible for policies concerning lake levels and shipping), regulatory practices have reduced peak annual levels during high water years on Lake Superior by one foot or more (Fig. 7). If the IJC projections are correct, it appears that their efforts have helped reduce wave erosion and bluff retreat on Lake Superior. Weighed against other forces and factors influencing shore erosion such as storm magnitude and frequency and foot ice development, however, it is difficult to say how much significance should be ascribed to the control at Sault Ste. Marie. However, it is noteworthy that the amount of regulation is greatest in spring and again in late summer and early fall when storm magnitude and frequency are rising and bluff erosion is normally advancing.

The IJC also recognizes the issue of the effect of the release rates of water from Lake Superior on the levels of the lower lakes. Although regulation of the Lake Superior release rate can be shown to have a very small effect on the levels of the lower lakes, from a political standpoint it is a no-win situation because a policy that favors property owners along the lower lakes injures property owners along Lake Superior and vice versa; at least that is the way it is commonly viewed.

The recent episode of high water and shore erosion, which ended in 1988, brought on a new wave of public pressure for additional controls on high lake levels. In response to a request from Michigan's Governor James Blanchard, the IJC has agreed to conduct a feasibility study on the construction of a diversion channel from Lake Erie to Lake Ontario to increase release rates during high water periods (Michigan De- partment of Natural Resources 1987). The option of increased outflows through the Chicago River is another consideration, but the idea is currently opposed by Illinois Governor James Thompson because of possible effects of the added discharge on flood flows on the Illinois River (Michigan Department of Natural Resources 1987). On balance, it appears likely that some sort of plan for additional diversion will be formulated for the middle lakes (Michigan, Huron, and Erie), where property damage and political pressure are greatest. Because the net effect of existing diversions is very small (Table 1), new diversion measures would have to be significantly more effective in order to reduce shore erosion. According to Quinn (1985), one diversion plan involving the Missouri River Basin would lower Lakes Michigan and Huron by $22 \mathrm{~cm}$. In the long run reduction of peak levels could affect bluff stability and nourishment of perched sand dunes such as those at Sleeping Bear, South Manitou Island, and Empire in northern Lake Michigan. Also, the relatively high water levels experienced over the past 50 years are, according to Quinn (1986), likely to remain high for six to ten more years, and in turn may fuel public pressure to advance new lake level control programs. The lower water of 1988-1989, however, appears to have quelled public and political pressure for the present.

One other management practice deserves mention: the practice of erosion control and dune stabilization with vegetation plantings. This practice is traditionally endorsed by the U.S. Soil Conservation Service as a control measure against wind erosion on agricultural lands. The practice has been extended to coastal areas - with varying degrees of success - driven by the motivation that erosion, no matter where it occurs, is always bad or at least a nuisance (e.g., Lehotsky 1941; Whitfield and Brown 1948; Woodhouse 1978). The Indiana Dunes National Lakeshore, for instance, has instituted a planting program to stabilize the face of its principal sand dune (Engquist 1987, personal communication). The dune face forms a long ramp leading from the shore to the dune crest and is the primary source of sand for the upper dune.

The wisdom of such erosion control programs is open to question. Those efforts limited to repairing surfaces damaged by foot or vehicle traffic are unquestionably appropriate, but ambitious programs aimed at vegetating bluff exposures can interfere with dune nourishment, especially if planting is carried out during low water periods when geomorphic activity on bluffs is low and the vegetation can become secure over a number of years. Clearly, management programs for coastal sand dunes, especially perched 


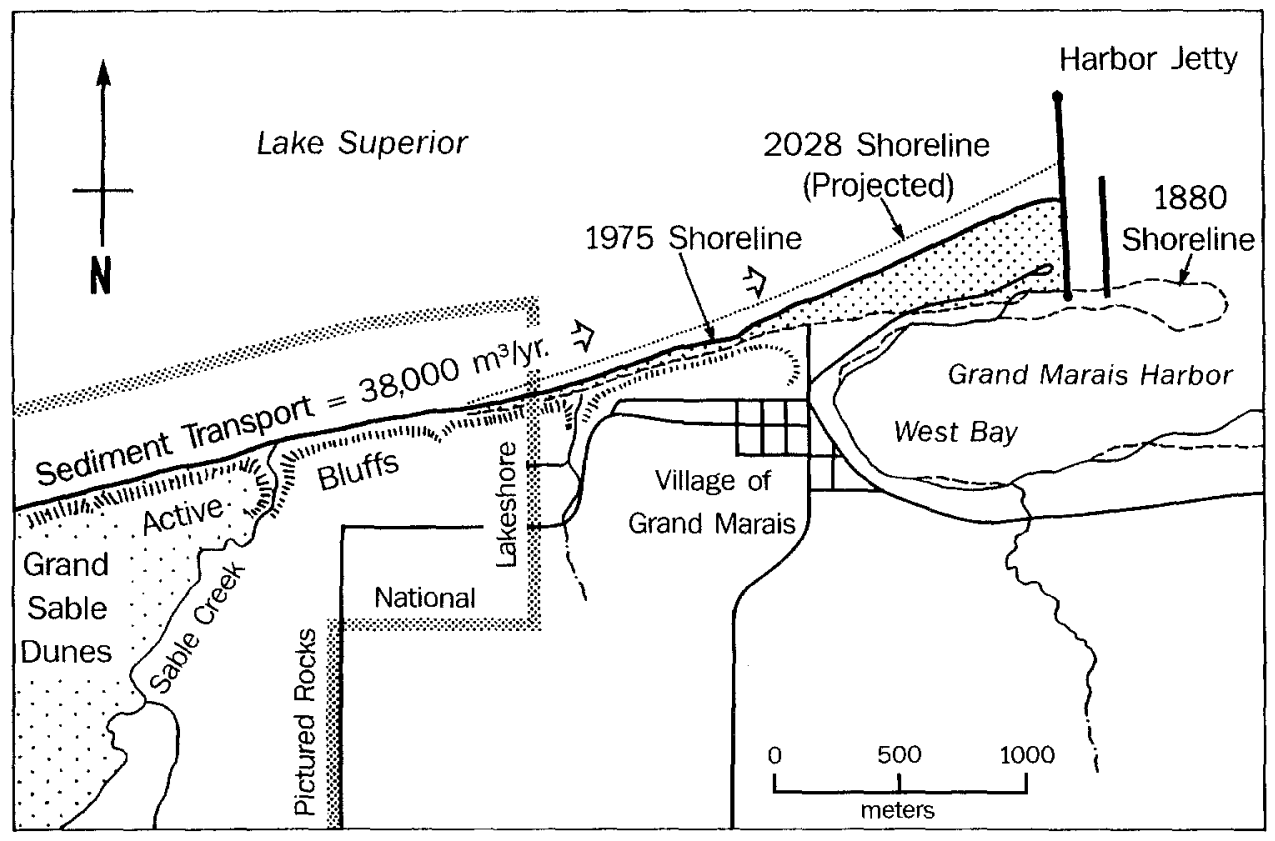

Figure 6. Sand accumulation associated with the breakwater of Grand Marais Harbor. The 1880 and 1975 shorelines and the projected shoreline for 2028 are shown. (U.S. Army Corps of Engineers 1980).

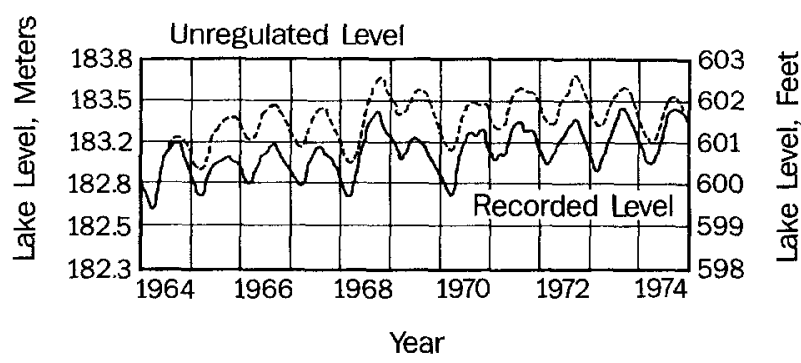

Figure 7. Regulated and unregulated levels of Lake Superior, 1964-1974. During this period, regulation reduced peak annual levels by one foot or more in five of 11 years (International Joint Commission 1976).

dunes, must be based on a understanding of the nourishment system and the source of sand. It is necessary for managers to understand that the principal control on wind erosion of sand is the geomorphic state of the bluff and that dune nourishment depends on an actively retreating bluff free of trees and groundcover on the upper slope.

\section{Summary}

The nourishment of sand dunes in the Great Lakes is related to lake level fluctuations. This can be shown for long-term level changes by the loss of nourishment and the eventual stabilization of dunefields with the abandonment of bluffs and shorelines as the Great Lakes fell to their present levels. Observed in a shorter time frame, it appears that nourishment to low-elevation dunes increases with wider beaches at lower lake levels. Conversely, nourishment to perched sand dunes increases with higher lake levels as erosion and mass movement denude bluffs and expose sandy substrata to wind erosion. This has implications for Great Lakes management policy because the maintenance of perched dunefields such as Grand Sable and Sleeping Bear is dependent on sand input from active bluffs on their lakeward edges. Active bluffs are maintained in large part by high water levels, the main culprit of shore erosion and property loss in the Great Lakes basin.

In the past decade public concern over shore erosion has reached critical levels in many parts of the Great Lakes. Although water levels have been relatively high since the 1940 s, most of the concern is attributable to increased development of shorelands and elevated real estate values over most of the Great Lakes. Political pressure to institute management controls on high water levels has widespread support, although it has subsided with the low water of 1988-1989. Diversion has been given the most serious attention, despite the fact that its effectiveness in reducing peak levels is projected to be small. Given an ambitious diversion program, however, the long-term stability of high bluffs could be improved, resulting in strengthened plant covers and reduced wind erosion on their upper reaches. 
Table 1. Diversions relative to natural fluctuations ${ }^{a}$

\begin{tabular}{lccc}
\hline Lake & $\begin{array}{c}\text { Effects of existing } \\
\text { diversions on mean } \\
\text { water levels }(\mathrm{m})^{\mathrm{b}}\end{array}$ & \multicolumn{2}{c}{ Range of natural fluctuations (m) } \\
\cline { 3 - 4 } Superior & +0.02 & Mean seasonal & Long term \\
Michigan-Huron & +0.01 & 0.32 & 1.17 \\
Erie & -0.10 & 0.30 & 2.01 \\
Ontario & +0.02 & 0.38 & 1.83 \\
\hline
\end{tabular}

'Source: Quinn (1985).

bInternational Great Lakes Diversions and Consumptive Uses Study Board (1981).

National Ocean Service (1982).

Water level regulation has long been practiced by the U.S. Army Corps of Engineers for Lake Superior. The annual peak, according to the Corps' calculations, is lower by about one foot in most high water years relative to the comparable unregulated level. This undoubtedly has an effect on shore erosion rates, although it is impossible to say how much. Locally, harbor protection facilities also influence shore erosion and deposition patterns over adjacent reaches of shoreline up to several kilometers in length. At Grand Marais, Michigan, the large jetty at the harbor mouth has caused the build up of a large wedge of sand that has extended as much as $3,000 \mathrm{~m}$ toward the Grand Sable Bluff. Behind this deposit, backshore slope erosion has diminished and much of the bank has become vegetated.

Sand dune stabilization with vegetative plantings has long been practiced in coastal areas, and the National Park Service utilizes plantings in selective locations to stabilize exposed sand. Although such plantings are appropriate for damaged areas, they are inappropriate for free faces that function as sand source areas such as bluffs and truncated dunes along the backshore.

\section{Acknowledgments}

Graphics were prepared by Nina L. Marsh. B. D. Marsh and W. R. Marsh participated in the original field research which was supported by the Planetary Geology and Geophysics Branch, Solar System Exploration Division of NASA. Research was also supported in part by a grant from the Faculty Development Fund of the University of Michigan-Flint.

\section{References Cited}

Bagnold, R. A., 1953, The Physics of Blown Sand and Desert Dunes: New York, William Morrow, 265 p.

Bergquist, S. G.., 1936, The Grand Sable Dunes on Lake Superior: Michigan Academy of Science, Arts and Letters, v. 21 , p. $429-438$
Bowen, A. J., and D. Lindley, 1977, A wind tunnel investigation of wind speed and turbulence characteristics close to the ground over various escarpment shapes: BoundaryLayer Meteorology, v. 12, p. 259-271.

Cooper, W.S., 1958, Coastal sand dunes of Oregon and Washington. The Geological Society of America, p. 169.

Dozier, J., J. Mitchell, and W. M. Marsh, 1976, Modeling of backslope processes during the cold season, south shore of Lake Superior: Review Geographic Montreal, v. 30, p. 1-2, $171-177$

Hughes, J.D., and W.J. Merry, 1978, Marquette buried forest 9850 years old: Abstracts of papers of the 144th national meeting, American Association for the Advancement of Science.

International Great Lakes Diversions and Consumptive Uses Study Board, 1981, Great Lakes diversions and consumptive uses: Report to the International Joint Commission.

International Joint Commission, 1976, Further regulation of the Great Lakes, Canada and United States: $96 \mathrm{p}$.

Jennings, J. N., 1967, Cliff-top dunes: Australian Geographical Studies, v. 5, p. 40-49.

Larson, C., 1973, Variation in bluff recession in relation to lake level fluctuation: Chicago, Illinois Institute of Environmental Quality.

Lehotsky, K., 1941, Sand dune fixation in Michigan: Journal of Forestry, v. 39, p. 12, 998-1004.

Lewis, C. F. M., 1969, Late Quaternary history of lake levels in the Huron and Erie basins: Proceedings, 12th Conference on Great Lakes Research, p. 250-270.

Marsh, W. M., and B. D. Marsh, 1987, Wind erosion and sand dune formation on high Lake Superior bluffs: Geografiska Annaler, v. 69A, no. 3-4, p. 379-391.

Marsh, W. M., B. D. Marsh, and J. Dozier, 1973, Formation, structure, and geomorphic influence of Lake Superior icefoots: American Journal of Science, v. 273, p. 48-61.

Michigan Department of Natural Resources, 1987, State of the Great Lakes: annual report for 1986: Lansing, MI, $40 \mathrm{p}$.

National Ocean Service, 1982, Great Lakes water levels, 1860-1980: Rockville, MD, NOAA, U.S. Department of Commerce.

Olson, J. S., 1958, Lake Michigan dune development: 3. lake level, beach and dune oscillation: Journal of Geology, v. 66, p. $245-263$. 
Quinn, F. H., 1985, Implications of the interbasin diversions, consumptive use, and the greenhouse effect on future Great Lakes water management: Preprint vol: Sixth Conference on Hydrometeorology, American Meteorological Society, p. 145-148.

Quinn, F. H., 1986, Causes and consequences of the record high 1985 Great Lakes water levels: Conference on climate and water management-a critical era, and Conference on the human consequences of 1985's climate (Preprint vol.) American Meteorological Society, p. 281-284.

U.S. Army Corps of Engineers, 1971, U.S. national shoreline study: Washington, D.C.
U.S. Army Corps of Engineers, 1980, Final detailed project report on shore damage of Grand Marais Harbor, Michigan: Section III: Detroit, MI, Detroit District.

White, B. R., 1979, Soil transport by winds on Mars: Journal of Geophysical Research, v. 84, p. 4643-4651.

Whitfield, C. J., and R. L. Brown, 1948, Grasses that fix sand dunes: yearbook of agriculture 1948: Washington, D.C., U.S. Department of Agriculture, p. 70-74.

Woodhouse, W. W., 1978, Dune building and stabilization with vegetation: special report: Fort Belvoir, VA, Department of the Army, Coastal Engineering Research Center, 112 p. 